\title{
OPEN
}

\section{Author Correction: Characterization of Sex-Based Dna Methylation Signatures in the Airways During Early Life}

\author{
Cesar L. Nino, Geovanny F. Perez, Natalia Isaza, Maria J. Gutierrez, Jose L. Gomez \& \\ Gustavo Nino
}

Correction to: Scientific Reports https://doi.org/10.1038/s41598-018-23063-5, published online 03 April 2018

This Article contains a typographical error in the Results section, under the sub-heading 'Nasal airway $\mathrm{X}$-chromosome DNA methylation of immune genes'.

"To accomplish this we constructed a list of X-linked immune genes (Supplementary Table 4) compiling information from two large Gene Ontology databases: PANTHER (Protein ANalysis THrough Evolutionary Relationships; http://www.pantherdb.org/) ${ }^{23}$ and IRIS (Immunogenetic Related Information Source) ${ }^{24 . "}$

should read:

"To accomplish this we constructed a list of X-linked immune genes compiling information from two large Gene Ontology databases: PANTHER (Protein ANalysis THrough Evolutionary Relationships; http://www.pantherdb. $\operatorname{org} /)^{23}$ and IRIS (Immunogenetic Related Information Source) $)^{24}$."

(c) (i) Open Access This article is licensed under a Creative Commons Attribution 4.0 International License, which permits use, sharing, adaptation, distribution and reproduction in any medium or format, as long as you give appropriate credit to the original author(s) and the source, provide a link to the Creative Commons license, and indicate if changes were made. The images or other third party material in this article are included in the article's Creative Commons license, unless indicated otherwise in a credit line to the material. If material is not included in the article's Creative Commons license and your intended use is not permitted by statutory regulation or exceeds the permitted use, you will need to obtain permission directly from the copyright holder. To view a copy of this license, visit http://creativecommons.org/licenses/by/4.0/.

(C) The Author(s) 2020 